\title{
Effect of phosphorus and zinc on yield of lentil
}

\author{
Abid Ali, Bashir Ahmad, Iqbal Hussain, Akhtar Ali* and Fawad Ali \\ Shah \\ Department of Agronomy The University of Agriculture, Peshawar-Pakistan \\ *Corresponding author email: akhtarali@aup.edu.pk
}

Citation

Abid Ali, Bashir Ahmad, Iqbal Hussain, Akhtar Ali and Fawad Ali Shah. Effect of phosphorus and zinc on yield of lentil. Pure and Applied Biology. http://dx.doi.org/10.19045/bspab.2017.600150

\begin{tabular}{llll}
\hline \hline Received: 16/02/2017 & Revised: 04/10/2017 & Accepted: 07/10/2017 & Online First: 30/10/2017 \\
\hline
\end{tabular}

\section{Abstract}

Fertilization of lentil (Lens culinaris) is one of the most crucial management technique which affects growth and yield. Therefore the present research was designed to investigate the response of lentil to various phosphorus and zinc levels at Agronomy Research Farm the University of Agriculture, Peshawar during rabi season 2015. The experiment was laid out in randomized complete block design (RCBD) having three replications.Five doses of phosphorus $\left(40,60,80,100\right.$, and $\left.120 \mathrm{~kg} \mathrm{ha}^{-1}\right)$ and four levels of zinc $\left(3,6,9\right.$, and $\left.12 \mathrm{~kg} \mathrm{ha}^{-1}\right)$ along with one control (No P and Zn) was used in the experiment. Number of pods plant ${ }^{-1}$, thousand grains weight, grain yield and seed recovery percentage was significantly influenced by different doses of both phosphorus and zinc. More pods plant ${ }^{-1}(118)$ and (122), thousand grain weight $(30 \mathrm{~g})$ and $(29.6 \mathrm{~g})$, grain yield $\left(2021.3 \mathrm{~kg} \mathrm{ha}^{-1}\right)$ and $\left(2047.5 \mathrm{~kg} \mathrm{ha}^{-1}\right)$ and maximum seed recovery of $69 \%$ were noted from the plots received 100 and $120 \mathrm{~kg} \mathrm{P}^{-1}$ respectively. Similarly the application of zinc at $9 \mathrm{~kg} \mathrm{ha}^{-1}$ produced morepods plant ${ }^{-1}(117)$ and grain yield $\left(1846 \mathrm{~kg} \mathrm{ha}^{-1}\right)$. Statistically similar results were found in plots received 9 and $12 \mathrm{~kg} \mathrm{Zn} \mathrm{ha}$ ${ }^{1}$ regarding thousand grain weights $(30.6 \mathrm{~g}$ and $29.4 \mathrm{~g})$ and seeds recovery percentage $(68 \%)$. The above all experimental results concluded that phosphorus and zinc should be used at the rates of $100 \mathrm{~kg} \mathrm{ha}^{-1}$ and $9 \mathrm{~kg} \mathrm{ha}^{-1}$ for the growth and yield of lentil.

Keywords: Lentil; Phosphorus; Zinc; Yield components; Yield

\section{Introduction}

Lentil (Lens culinaris) is an important annual leguminous crop which is locally called "Masoor" belongs to the family Fabaceae. Human diet consists of vegetable protein in good amount. Lentil contains protein, carbohydrates, oils, and ash at the rate of $23.25 \%, 59 \%, 1.8 \%$ and $0.2 \%$ respectively along with iron, calcium, phosphorus and magnesium. A significant amount of vitamin A and B is also provided by lentil [1]. In crop productivity, nutrients management plays a vital role while less availability of nutrients causes reduction in yield and productivity. The insufficiency of macro and micro nutrients have been recorded in many soils and through various management practices it could be managed properly [2].

Lentil is a legume crop and plays a great role in crop rotation for maintaining soil fertility and through root nodules, lentil can fix atmospheric nitrogen by symbiotic rhizobia therefore fertilizers and soil fertility has a major role for obtaining higher yield [3]. Lentil can fix 8-14 kg N ha${ }^{1}$ and therefore the requirement of nitrogen to legume crops is low as compared to nonlegume crops [1]. Apart from nitrogen, phosphorus is also an important macro element for obtaining good quality and better growth of lentil. It has a significant 
role in nodules formation which helps in nitrogen fixation [4]. As the addition of phosphorus to soil increased yield of legumes, so a suitable dose of phosphorus should be determined for higher yield.

The role of micronutrients is also very important in growth and development of all the crops [5]. In micronutrients, zinc is very important in reproductive phase like fertilization and pollen grain formation as pollen grain contains a high amount of zinc. Most of the zinc is translocated to seeds during fertilization and lower application of zinc causes deficiency of zinc in the seed and also the seed yield is quietly reduced [68]. In dry land agriculture, the application of fertilizer increases the lentil quality (protein \%) and quantity (grain yield). For achieving these objectives, it is essential to select the most appropriate levels of phosphorus and zinc fertilizer in each area for the growth and better yield of lentil.

\section{Materials and methods}

\section{Site description}

Field research "Effect of various levels of phosphorus and zinc on yield of lentil" was carried out at Agronomy Research Farm, The University of Agriculture Peshawar during 2015. Randomized complete block design was used replicated three times. Five doses of phosphorus $(40,60,80,100$, and $\left.120 \mathrm{~kg} \mathrm{ha}^{-1}\right)$ and four levels of zinc (3, 6, 9, and $12 \mathrm{~kg} \mathrm{ha}^{-1}$ ) along with one control $\left(\mathrm{P}_{0} \mathrm{Zn}_{0}\right)$ was used in the experiment. Plot size of $3 \mathrm{~m} \times 1.5 \mathrm{~m}$ with R-R distance 30 $\mathrm{cm}$ was used. Lentil cultivar (Markaz-09) was sown at the seed rate of $30 \mathrm{~kg} \mathrm{ha}^{-1}$. Nitrogen at the rate of $50 \mathrm{~kg} \mathrm{ha}^{-1}$ was applied as a basal dose. Recommended irrigation schedule was followed; however changes were made due to weather condition when required. For weeds control hoeing were used. All other standard agronomic practices were applied equally to all experimental plot during the growing season.

\section{Statistical analysis}

Data was analyzed statistically through using ANOVA technique used for RCBD in agricultural crops experiments. LSD test was used for comparisons of means at $\mathrm{P} \leq$ 0.05 level probability.

\section{Results and discussion \\ Pods plant $^{-1}$}

Data regarding pods per plant of lentil as influenced by different levels of $\mathrm{P}$ and $\mathrm{Zn}$ is shown in table 1. Analysis of the data revealed that the effect of the treatments was significant on number of pods plant ${ }^{-1}$ while their interaction was found nonsignificant. Maximum pods (122) were noted when phosphorus at the amount of $120 \mathrm{~kg} \mathrm{ha}^{-1}$ was incorporated fallowed by (118) at $100 \mathrm{~kg} \mathrm{ha}^{-1}$ while minimum pods plant $^{-1}$ (98) were obtained at $40 \mathrm{~kg} \mathrm{ha}^{-1}$ which was statistically similar (102) with that of $60 \mathrm{~kg} \mathrm{ha}^{-1}$. It might be the reason of moderate plant nutrients availability due to which the plant produce more pods plant ${ }^{-1}$ as compare to other treatments and also phosphorus strongly increases the reproduction of the plants i.e. flowering and fruiting. These results were similar with that of $[9,10]$.For zinc maximum pods (117) were noticed when zinc was used at the amount of $9 \mathrm{~kg} \mathrm{ha}^{-1}$ while fewer pods plant $^{-1}$ (103) were counted when zinc was used at $3 \mathrm{~kg} \mathrm{ha}^{-1}$. Zinc has a greater role in the production of Auxine and indole acetic acid (IAA), which helps in the regulation of plant growth which in turn resulted in more pods per plant [11]. Another reason is that zinc helps in more number of branches due to the formation of stamens and pollens [12].Analysis about comparing control vs. rest of the applied treatments was also found significant. More number of pods plant ${ }^{-1}(110)$ were seen in treated plots against control plots (96).

\section{Thousand grains weight (g)}

Thousand grains weight (g) of lentil is given in table 1. It is observed from the data that phosphorus, zinc and their interaction had significant effect on thousand grains weight. Control vs. rest treatments comparison were also found significant. Maximum thousand grain weight $(30 \mathrm{~g})$ and (29.6 g) was obtained at 100 and $120 \mathrm{~kg} \mathrm{P}$ $\mathrm{ha}^{-1}$ while minimum thousand grain weight $(27.6 \mathrm{~g})$ was obtained at $40 \mathrm{~kg} \mathrm{P} \mathrm{ha}^{-1}$ which 
was statistically alike with 60 and $80 \mathrm{~kg} \mathrm{p}$ $\mathrm{ha}^{-1}$. The possible reason for thousand grain weight could be the effect of cell division, phosphorus contents present inside the seed as well as the formation of albumin and fats [13-15]. For zinc, maximum thousand grain weights $(30.6 \mathrm{~g})$ was observed at the rate of $9 \mathrm{~kg} \mathrm{ha}^{-1}$ while minimum 1000 grain weight $(26.1 \mathrm{~g})$ was observed at $3 \mathrm{~kg} \mathrm{Zn} \mathrm{ha}{ }^{-1}$. The optimal level of zinc affects cell division, starch and sugar formation which might be the cause of increase 1000 grain weight by increasing the size and weight of the seed [16]. Thousand grain weight is improved by the optimal level of Zinc [17].Value recorded for control was (23 g) while that of treated plots was (28.6 g).

Table 1. Number of pods per plant, thousand grain weight and grain yield of lentil as influenced by different levels of phosphorus and zinc

\begin{tabular}{|c|c|c|c|}
\hline Phosphorus (kg ha' ${ }^{-1}$ ) & Pods plant $^{-1}$ & 1000 grain weight $(\mathrm{g})$ & Grain yield (kg ha-1) \\
\hline 40 & $98 \mathrm{c}$ & $27.6 \mathrm{~b}$ & $1239 \mathrm{c}$ \\
\hline 60 & $102 \mathrm{c}$ & $27.8 \mathrm{~b}$ & $1521 \mathrm{~b}$ \\
\hline 80 & $111 \mathrm{~b}$ & $27.9 \mathrm{~b}$ & $1606 \mathrm{~b}$ \\
\hline 100 & $118 \mathrm{a}$ & $30.0 \mathrm{a}$ & $2021 \mathrm{a}$ \\
\hline 120 & $122 \mathrm{a}$ & $29.6 \mathrm{a}$ & $2048 \mathrm{a}$ \\
\hline $\operatorname{LSD}(0.05)$ & 4.37 & 1.48 & 88 \\
\hline \multicolumn{2}{|l|}{ Zinc $\left(\mathrm{kg} \mathrm{ha}^{-1}\right)$} & $\sqrt{2}+2$ & \\
\hline 3 & $103 \mathrm{c}$ & $26.1 \mathrm{c}$ & $1574 \mathrm{c}$ \\
\hline 6 & $110 \mathrm{~b}$ & $28.1 \mathrm{~b}$ & $1642 b c$ \\
\hline 9 & $117 \mathrm{a}$ & $30.6 \mathrm{a}$ & $1846 \mathrm{a}$ \\
\hline 12 & $111 \mathrm{~b}$ & $29.4 \mathrm{ab}$ & $1686 \mathrm{~b}$ \\
\hline $\operatorname{LSD}(0.05)$ & 3.91 & 1.32 & 79 \\
\hline \multicolumn{3}{|c|}{ Planned mean comparison } & \\
\hline Control & 96 & 23.0 & 753 \\
\hline Rest & 110 & 28.6 & 1687 \\
\hline \multicolumn{4}{|l|}{ Interaction } \\
\hline $\mathrm{PXZ}$ & ns & ns & $*$ \\
\hline
\end{tabular}

Ns = non-significant

Means in columns and rows with different alphabets differ significantly from each other at $\mathrm{p} \leq 0.05$ using LSD

\section{Grain yield $\left(\mathrm{kg} \mathrm{ha}^{-1}\right)$}

Grain yield $\mathrm{kg} \mathrm{ha}^{-1}$ as influenced by different levels of phosphorus and zinc is shown in table 1. Phosphorus and zinc application significantly increased the grain yield. The interaction between phosphorus and zinc and comparison of control vs. rest treatment were found significant. Treated plots improved the grain yield $\left(1687 \mathrm{~kg} \mathrm{ha}^{-}\right.$ $\left.{ }^{1}\right)$ as compared to control $\left(753.1 \mathrm{~kg} \mathrm{ha}^{-1}\right)$. More grain yield $\left(2047.5 \mathrm{~kg} \mathrm{ha}^{-1}\right)$ was obtained from the plots received $120 \mathrm{~kg} P$ $\mathrm{ha}^{-1}$ which was statistically same with $\left(2021.3 \mathrm{~kg} \mathrm{ha}^{-1}\right)$ at $100 \mathrm{~kg} \mathrm{ha}^{-1}$ while the application of phosphorus at the rate of 40 $\mathrm{kg} \mathrm{ha}^{-1}$ resulted lowest grain yield (1238.9 $\mathrm{kg} \mathrm{ha}^{-1}$ ). The reason for increasing grain yield is the balance nutrient supply and timely application of the nutrients which enhances the plant growth and the grain yield will be increased. Similar results support that increasing phosphorus level, the grain yield increased too $[18,19]$. In case of zinc the higher grain yield $(1846 \mathrm{~kg}$ $\mathrm{ha}^{-1}$ ) was obtained at $9 \mathrm{~kg} \mathrm{Zn} \mathrm{ha}^{-1}$ while lowest grain yield (1574 $\left.\mathrm{kg} \mathrm{ha}^{-1}\right)$ was recorded at $3 \mathrm{~kg} \mathrm{Zn} \mathrm{ha-1.} \mathrm{Similar} \mathrm{results}$ were reported on the grain yield [20-22]. 
Increasing $\mathrm{P}$ and $\mathrm{Zn}$ level (Figure 1) from 40-100 and 3-9 $\mathrm{kg} \mathrm{ha}^{-1}$ respectively had synergistic effect on each other and significant increase in the grain yield was observed. Beyond $100 \mathrm{~kg} \mathrm{P}$ and $9 \mathrm{~kg} \mathrm{Zn} \mathrm{ha-}$

${ }^{1}$ had no significant effect on grain yield.

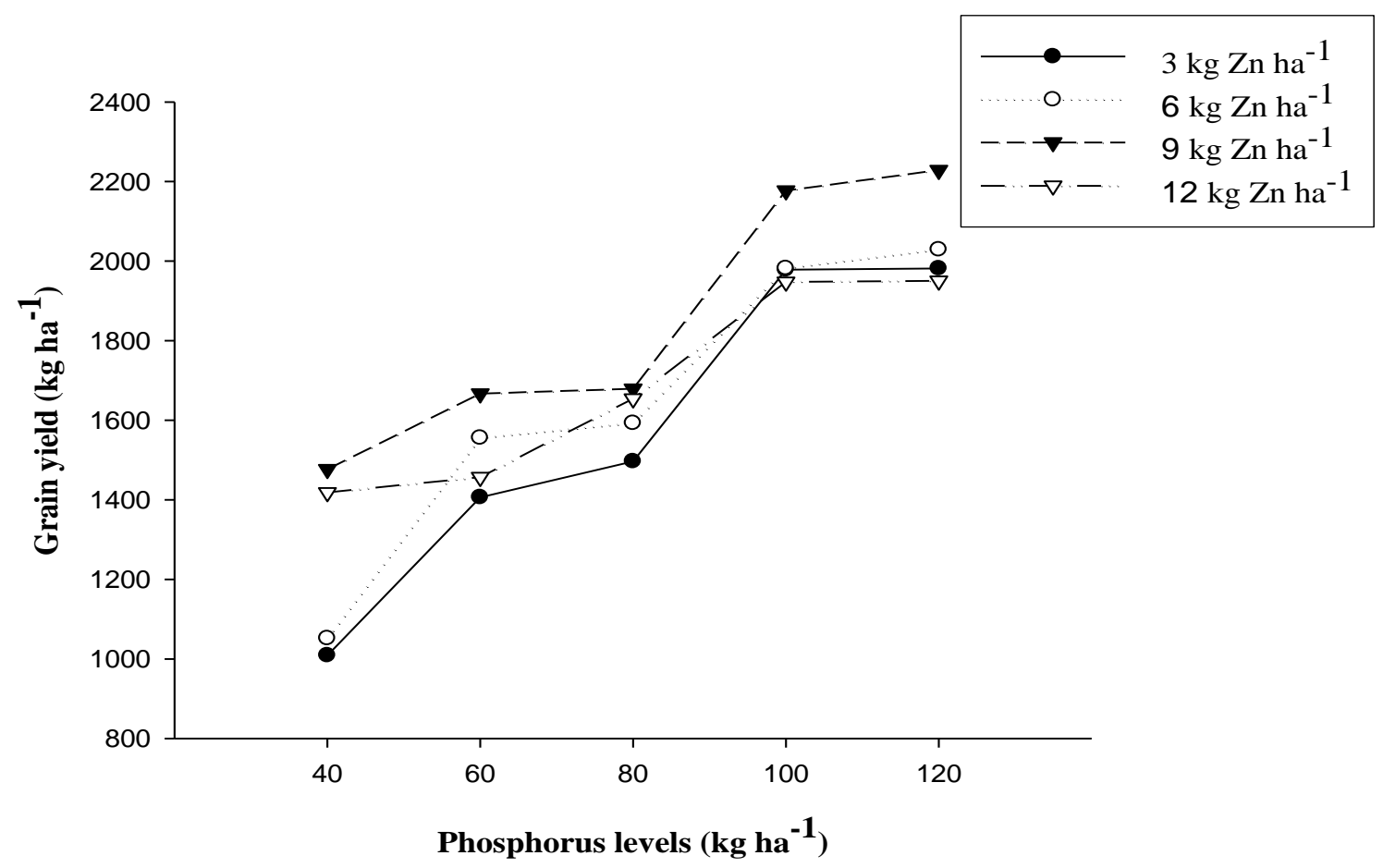

Figure 1. Interaction of phosphorus (P) and zinc (Zn) application for grain yield (kg ha' ${ }^{1}$ of lentil

Seed recovery $(\%)$

Seed recovery of lentil was affected significantly by phosphorus and zinc and is given in table 2. Phosphorous and $\mathrm{Zn}$ had important effect on seed recovery percentage. The interaction between $\mathrm{P}$ and $\mathrm{Zn}$ showed non-significant effect. Maximum seeds recovery (number of medium seed percentage) was shown by treated plots $(67.1 \%)$ as compared to control plots $(59.4 \%)$. When phosphorus rate was increased from low to high level, a linear decreasing trend was observed and the number of small seeds decreased gradually from maximum to minimum. At lowest rate of phosphorus $40 \mathrm{~kg} \mathrm{ha}^{-1}$, the maximum number of small seeds $(31.6 \%)$ was observed while minimum small seeds $(22.2 \%)$ were observed at highest level of phosphorus $120 \mathrm{~kg} \mathrm{ha}^{-1}$. When phosphorus was applied at $120 \mathrm{~kg} \mathrm{ha}^{-1}$, the maximum medium seeds $(68.7 \%)$ were observed while the minimum seeds $(64.8 \%)$ were conted at $40 \mathrm{~kg} \mathrm{P} \mathrm{ha}^{-1}$. Similarly data about bold seeds, so at $120 \mathrm{~kg} \mathrm{Pha}{ }^{-1}$, more numbers of bold seeds were recorded $(9.2$ $\%)$ while less percent of bold seeds $(3.7 \%)$ were observed at $40 \mathrm{~kg} \mathrm{P} \mathrm{ha}^{-1}$. In case of zinc more number of small seeds $(27.5 \%)$ was noted in plots received $3 \mathrm{~kg} \mathrm{Zn} \mathrm{ha-1}$ fallowed by (27.1\%) at $6 \mathrm{~kg} \mathrm{Zn} \mathrm{ha}^{-1}$ while less number of seeds $(25.6 \%)$ was observed at 9 and $12 \mathrm{~kg} \mathrm{ha}^{-1}$. At higher doses of zinc $12 \mathrm{~kg} \mathrm{ha}^{-1}$ and $9 \mathrm{~kg} \mathrm{ha}^{-1}$, maximum numbers of medium seeds $(67.7 \%)$ were recorded while minimum numbers of medium seeds $(66.4 \%)$ were recorded at $3 \mathrm{~kg} \mathrm{ha}^{-1}$ which was at far with $6 \mathrm{~kg} \mathrm{ha}^{-1}(66.7 \%)$. More number of bold seeds $(6.8 \%)$ were recorded when zinc was applied at $12 \mathrm{~kg} \mathrm{ha}^{-}$ 1 fallowed by $(6.7 \%)$ at $9 \mathrm{~kg} \mathrm{ha}^{-1}$ while minimum number of bold seeds $(6.1 \%)$ were recorded at $3 \mathrm{~kg} \mathrm{ha}^{-1}$ and $6 \mathrm{~kg} \mathrm{ha}^{-1}$. The reason for this increase in seed size might be the fact that phosphorus and zinc play role in photosynthesis, enzymes activation, fertilization and translocation of assimilates towards the seeds [23]. 
Table 2. Seed recovery $(\%)$ of lentil as affected by different levels of phosphorus and zinc

\begin{tabular}{|c|c|c|c|}
\hline $\begin{array}{c}\text { Phosphorus (P) } \\
\text { kg ha }^{-1}\end{array}$ & $\begin{array}{c}\text { Small seeds } \\
(<10 \times m m)\end{array}$ & $\begin{array}{l}\text { Medium seeds } \\
(<12 \mathrm{~mm})\end{array}$ & $\begin{array}{l}\text { Bold seeds } \\
(>12 \mathrm{~mm})\end{array}$ \\
\hline 40 & $31.6 \mathrm{a}$ & $64.8 \mathrm{c}$ & $3.7 \mathrm{e}$ \\
\hline 60 & $28.9 \mathrm{~b}$ & $66.4 \mathrm{~b}$ & $4.8 \mathrm{~d}$ \\
\hline 80 & $26.1 \mathrm{c}$ & $67.1 \mathrm{~b}$ & $6.9 \mathrm{c}$ \\
\hline 100 & $23.9 \mathrm{~d}$ & $68.6 \mathrm{a}$ & $7.7 \mathrm{~b}$ \\
\hline 120 & $22.2 \mathrm{e}$ & $68.7 \mathrm{a}$ & $9.2 \mathrm{a}$ \\
\hline LSD (0.05) & 0.931 & 1.026 & 0.653 \\
\hline \multicolumn{4}{|l|}{ Zinc (Zn) kg ha ${ }^{-1}$} \\
\hline 3 & $27.5 \mathrm{a}$ & $66.4 \mathrm{c}$ & $6.1 \mathrm{c}$ \\
\hline 6 & $27.1 \mathrm{a}$ & $66.7 \mathrm{bc}$ & $6.2 \mathrm{bc}$ \\
\hline 9 & $25.6 \mathrm{~b}$ & $67.7 \mathrm{a}$ & $6.7 \mathrm{ab}$ \\
\hline 12 & $26.0 \mathrm{~b}$ & $67.5 \mathrm{ab}$ & $6.8 \mathrm{a}$ \\
\hline LSD (0.05) & 0.833 & 0.918 & 0.584 \\
\hline \multicolumn{4}{|c|}{ Planned mean comparison } \\
\hline Control & 37.7 & 59.4 & 2.4 \\
\hline Rest & 26.5 & 67.1 & 6.4 \\
\hline \multicolumn{4}{|l|}{ Interactive effect } \\
\hline $\mathrm{P} \times \mathrm{Zn}$ & $\mathrm{ns}$ & ns & ns \\
\hline
\end{tabular}

Ns $=$ non-significant

Means in columns and rows with different alphabets differ significantly from each other at $\mathrm{p} \leq 0.05$ using LSD

\section{Conclusion and recommendations}

From the findings of our experiment, it is concluded that the application of phosphorus at the rate of 100 and $120 \mathrm{~kg} \mathrm{ha}^{-}$ ${ }^{1}$ gave the best result regarding yield and yield components of lentil while in case of zinc the use of $9 \mathrm{~kg} \mathrm{ha}^{-1}$ were found best in terms of yield and its components. So for the achievement of higher yield of lentil, phosphorus at the rate of $100 \mathrm{~kg} \mathrm{ha}^{-1}$ while zinc at the rate of $9 \mathrm{~kg} \mathrm{ha}^{-1}$ should be applied.

\section{Authors' contributions}

Conceived and designed the experiments: A Ali \& B Ahmad, Performed the experiments: A Ali, Analyzed the data: Abid Ali \&Akhtar Ali, Contributed reagents/ materials/ analysis tools: I Hussain \& FA Shah, Wrote the paper: A Ali.

\section{References}

1. Zafar M, Maqsood M, Anser MR \& Ali $\mathrm{Z}$ (2003). Growth and yield of lentil as affected by phosphorus. Int. J Agri and Bio 5(1):98-100.

2. Ali S, Khan AR, Mairaj G, Arif M, Fida M \& Bibi S (2008). Assessment of different crop nutrient management practices for yield improvement. Aus $J$ Crop Sci2:150-157.

3. Crook DG, Ellis RH \& Summerfield RJ (1999). Winter sown lentil and its impact on subsequent cereal crop. Aspects of Appl Bio 56: 241-248.

4. Sepetoglu H (2002). Grain legumes. Department of Field Crops, Faculty of Agriculture, University of Ege Publication: 24/4, Izmir, Turkey.

5. Farooq M, Wahid A \& Siddique KHM (2012). Micronutrient application through seed treatments: a review. J Soil Sciand Plant Nutri 12: 125-142.

6. Jenik PD \& Kathryn BM (2005). Surge and destroy: the role of auxin in plant embryogenesis. Development132 (3): 577-585. 
7. Pandey SN \& Gautam S (2009). Effects of zinc supply on its uptake, growth and biochemical constituents in lentil. Indian J Plant Physio 14(1): 6770.

8. Reid DE, Ferguson BJ, Hayashi S, Lin YH \& Gresshoff PM (2011). Molecular mechanisms controlling legume auto regulation of nodulation. Annals of Bot 108: 789-95.

9. Saleh SA (1976). Response of six soybean varieties to phosphorus fertilizer at wadi Jizan region, Saudi Arabia. Annals Agric Sci Moshtohor 5: 3-10.

10. Jayapaul P \& Ganesaraja V (1990). Studies on response of soybean varieties to nitrogen and phosphorus. Indian $J$ Agric 35: 329-330.

11. Taliee A \& Sayadian K (2000). Effect of supplemental irrigation and plant nutrient in chickpea (dryfarming). $J$ Agron and Crop Sci 2: 213-218.

12. Nadergoli MS, Yarnia M \& Khoei FR (2011). Effect of zinc and manganese and their application method on yield and yield components of common bean. Middle-East J Sci Res 8: 859865.

13. Ali A (1979). Effect of plant nutrition on seed yield, mineral composition and cooking quality of lentil (Lens culinaris). M.Sc. Thesis, Dept. Agron.Uni. Agri., Faisalabad, Pakistan.

14. Shamim M \& Naimat A (1987). Effect of seed inoculation with Rhizobium and N.P. fertilizer level on the yield of gram. Pakistan J Agri Res 8: 383-5.

15. Subramanian A \& Radhak A (1981). Effect of foliar spray on black gram pulse crop. Field Crop Absts 236(4): 3102-1983.
16. Khorgamy A \& Farina A (2009). Effect of phosphorus and zinc fertilization on yield and yield components of chick pea cultivars. African Crop Sci. Conference Proceedings 9: 205- 208.

17. Rathi BK, Jain AK, Kumar S \& Panwar JDS (2009). Response of Rhizobium inoculation with sulphur and micronutrients on yield and yield attributes of black gram. Legume Res 32: 62-64.

18. Singh OB, Shama HB \& Singh VK (1999). Effect of nitrogen, phosphorus and rhizobium culture on yield and yield attributes of lentil under dry land conditions. DeptAgron G.B Pant University Agri \& Tech Pantnagar Distt. Udham Singh Nagar 263145, India. Ind J Pulses Res12: 260-2.

19. Chaubey AK, Kushik MK \& Singh SB (1999). Response of lentil to phosphorus and zinc sulphate nutrition. Crop Res Hasar 17: 309-12.

20. Singh V, Kumar V \& Karawasra SPS (1995). Interaction of $S$ and Zn on dry matter yield, concentration and uptake of $S$ in green gram. Crop Res 9: 32-41.

21. Singh YP \& Singh R (2004). Interaction effect of sulphur and phosphorus on growth and nutrient content of black grow. J Ind Society of Soil Sci 52: 266269.

22. Singh D \& Singh H (2012). Effect of phosphorus and zinc nutrition on yield, nutrient uptake and quality of chickpea. Annals of Plant and Soil Res 14: 71-74.

23. Hussain I \& Ahmad B (2015). Effect of nitrogen and zinc application on growth, yield and seed recovery of wheat crop. MSc (Hons) thesis Dept of Agron KPK AgriUni Peshawar Pakistan. 